\title{
Influence of the type of lightweight clay brick on the equivalent thermal transmittance of different types of façades on buildings
}

\author{
M.P. Morales ${ }^{\mathrm{a}, \mathrm{b}}$, P. Muñoz ${ }^{\mathrm{c}}$, M.C. Juárez ${ }^{\mathrm{d}} \bowtie$, M.A. Mendívil ${ }^{\mathrm{d}}$, P. Olasolo ${ }^{\mathrm{d}}$ \\ a. Facultad de Ingeniería, Universidad Autónoma de Chile, (Providencia, Santiago, Chile) \\ b. Research Group: MOdelación Matemática Aplicada a la INgeniería (MOMAIN), Universidad Internacional de \\ La Rioja (UNIR),-(Logroño, Spain) \\ c. Facultad de Ingeniería Civil, Universidad Autónoma de Chile, Talca- Chile \\ d. Escuela Técnica Superior de Ingeniería Industrial. Universidad de La Rioja,-(Logroño, Spain) \\ $\triangle$ manuel.juarez@unirioja.es
}

Received 18 September 2015

Accepted 22 February 2016

Available on line 20 July 2016

ABSTRACT: This paper compares the equivalent thermal transmittances of different façades built using commercial clay bricks with three different thicknesses and façades made using the same method but with ceramic bricks with optimized rhomboidal interior geometry.

Equivalent thermal transmittances of $0.300 \mathrm{~W} / \mathrm{m}^{2} \cdot \mathrm{K}$ were recorded for the rhomboidal brick with a thickness of $0.290 \mathrm{~m}$ and a façade with thermo-acoustic insulation and a large format brick on the interior, but the final thickness of the façade was $0.445 \mathrm{~m}$.

For ventilated façades made of the proposed rhomboidal brick with thicknesses of 0.290 and $0.240 \mathrm{~m}$ an $8-9 \%$ improvement was found, with values of $0.312 \mathrm{~W} / \mathrm{m}^{2} \cdot \mathrm{K}$ and $0.339 \mathrm{~W} / \mathrm{m}^{2} \cdot \mathrm{K}$, respectively.

It can be concluded that in view of the small difference in thermal terms, the best option is to use a brick $0.240 \mathrm{~m}$ thick, as the overall thickness of the façade will not then exceed $0.300 \mathrm{~m}$.

KEYWORDS: Brick; Ceramic; Physical properties; Thermal analysis; Finite element method

Citation/Citar como: Morales, M.P.; Muñoz, P.; Juárez, M.C.; Mendívil, M.A.; Olasolo, P. (2016) Influence of the type of lightweight clay brick on the equivalent thermal transmittance of different types of façades on buildings. Mater. Construcc. 66 [323], e096. http://dx.doi.org/10.3989/mc.2016.08115.

RESUMEN: Influencia del tipo de bloque de arcilla aligerada en la transmitancia térmica equivalente de diferentes tipos de fachadas en edificios. En el presente trabajo se comparan las transmitancias térmicas equivalentes de diferentes fachadas ejecutadas con bloques comerciales de tres espesores $0,290 \mathrm{~m}, 0,240 \mathrm{~m}$ y $0,190 \mathrm{~m}$, con el mismo montaje pero con un bloque cerámico optimizado con geometría interior romboidal.

Se ha obtenido una transmitancia térmica equivalente de $0,300 \mathrm{~W} / \mathrm{m}^{2} \cdot \mathrm{K}$ para el ladrillo con geometría romboidal de $0,290 \mathrm{~m}$ de espesor y pared con aislamiento termoacústico y gran formato en el interior, con un espesor total de fachada de $0,445 \mathrm{~m}$.

Para fachadas ventiladas con el ladrillo romboidal propuesto con espesores de 0,290 y 0,240 m, se obtiene una mejora de un $8 \%-9 \%$, con valores de $0,312 \mathrm{~W} / \mathrm{m}^{2} \cdot \mathrm{K}$ y $0,339 \mathrm{~W} / \mathrm{m}^{2} \cdot \mathrm{K}$, respectivamente.

Podemos concluir que, dada la pequeña diferencia en términos térmicos, la mejor opción es el uso de ladrillos de $0,240 \mathrm{~m}$ de espesor, siempre y cuando el espesor total de fachada no exceda los $0,300 \mathrm{~m}$.

PALABRAS CLAVE: Ladrillo; Cerámica; Propiedades físicas; Análisis térmico; Método de los elementos finitos

Copyright: (C) 2016 CSIC. This is an open-access article distributed under the terms of the Creative Commons Attribution License (CC BY) Spain 3.0. 


\section{INTRODUCTION}

Improving the energy efficiency of machinery and premises is one of the most important ways of achieving global energy sustainability. Energy that is not used is the cheapest energy of all.

Many buildings are ecologically unsustainable: they are not environmentally friendly, and may even be causing pollution by consuming large quantities of energy, with the substantial harmful atmospheric emissions that this entails (1).

Buildings are large consumers of thermal energy. In fact, the residential and services sectors account for around $27 \%$ of the total energy consumed in the EU-28, i.e. 275 MTEP (Million-Ton Equivalent of Petroleum) (2). Much of this energy is used in air conditioning.

One construction solution for outer envelopes that is now being implemented to improve the thermal efficiency of buildings and reduce energy losses is to use low-density, "lightweight" clay bricks.

Recent studies have considered the impact of the cladding materials used on building walls on $\mathrm{CO}_{2}$ emissions, and their influence on energy consumption (3). Other studies have sought to further improve the materials used in building envelopes by showing how the porous nature of clay bricks can improve thermal characteristics (4-6).

Numerous studies have been conducted on the materials used in building envelopes. These studies have individually characterized the influence of the type of internal void in large format bricks (7-13) and the type of tongue and groove system $(14,15)$ as regards clay-air and clay-mortar cross-sections (see Fig. 7), along with the influence of the horizontal joint on the cross-section of the layer of bonding mortar itself (16). Recent studies have shown that optimizing the internal geometry of bricks with a thickness of $0.290 \mathrm{~m}$ may lead to improvements of as much as $23 \%$ in the equivalent thermal transmittance of single-leaf walls (17).

Other studies have looked at reducing the thermal conductivity of clay by using additives, and have shown how those additives reduce thermal conductivity due to gas micropores generated in the volume of baked clay (18-22). Industry manufacturers have added paper pulp to their clays, giving them conductivity levels of around $0.500 \mathrm{~W} / \mathrm{m} \cdot \mathrm{K}$. These clays are then used to make bricks called Termoarcilla ${ }^{\mathrm{TM}}$ in thicknesses of between $0.290 \mathrm{~m}$ and $0.140 \mathrm{~m}$.

The research reported here studies the possibility of improving the equivalent thermal transmittance of building façades by using bricks available on the market with thicknesses of $0.290 \mathrm{~m}, 0.240 \mathrm{~m}$ and $0.190 \mathrm{~m}$, and optimized internal geometry with rhomboidal internal voids $(7,8,9,11,12,13)$ on different types of façade. The focus is on single-leaf façades, ventilated façades, façades with an outside thermal insulation system, and façades with a thermo-acoustic insulation system with cladding made of large format bricks $0.070 \mathrm{~m}$ thick. As demonstrated below, these are the solutions that provide the best thermal results on today's market. This study also considers a continuous tongue and groove system, as propounded by several authors $(14,15)$.

Equivalent thermal transmittance, $U_{e q}\left[\mathrm{~W} / \mathrm{m}^{2} \cdot \mathrm{K}\right]$, is calculated in all cases in accordance with Spanish standards $(23,24)$, EN European Standards (25-30) and ISO International Standards $(31,32)$. The thermal conductivity of each uncoated brick proposed is calculated using COMSOL Multiphysics software (33).

\section{MATERIALS AND METHOD}

\subsection{Bricks under study}

As its reference product, the study took commercially available Termoarcilla ${ }^{\mathrm{TM}}$ bricks with a herringbone internal geometry and three different thicknesses (with "thickness" taken to mean the dimension in the direction of which heat flows through the wall): $0.290 \mathrm{~m}, 0.240 \mathrm{~m}$ and $0.190 \mathrm{~m}$, as shown in Fig. 1.

The bricks proposed in this research had a rhomboidal internal geometry and a tongue and groove configuration with internal voids extending into them, referred to as a "continuous tongue and groove system" (10). No changes were made in dimensions, so the height of $0.192 \mathrm{~m}$, length of $0.307 \mathrm{~m}$ and thicknesses of $0.290,0.240$ and 0.190 $\mathrm{m}$ found in the commercial bricks were maintained. These bricks are shown in Fig. 2.

The study considered the same clays used by the commercial manufacturers, with paper pulp as an additive. Clay conductivity was $0.500 \mathrm{~W} / \mathrm{m} \cdot \mathrm{K}$, measured by the hot plate method as specified in (35). This is a value reported by almost all the manufacturers of Termoarcilla ${ }^{\mathrm{TM}}$ bricks consulted. The same

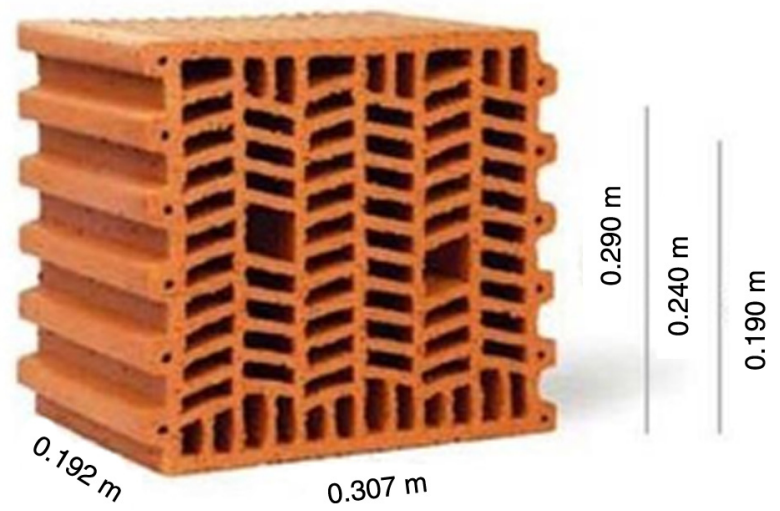

Figure 1. Commercial Termoarcilla ${ }^{\mathrm{TM}}$ brick (34). 


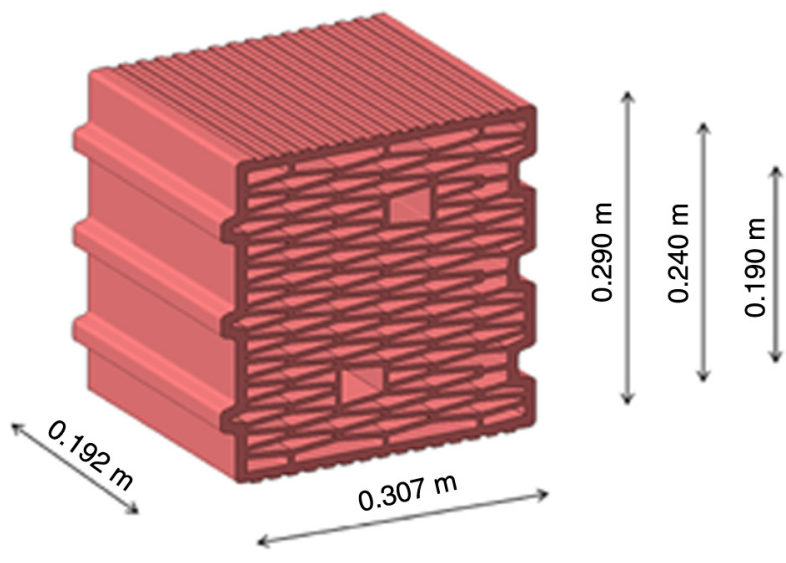

FIGURE 2. Proposed bricks with rhomboidal internal voids.

conductivity level was considered in all the bricks under study so that the thermal results could be compared.

\subsection{Building solutions for the façades under study}

Each different type of façade involves the use of bonding mortars as horizontal joint, plaster renderings and other cladding materials. The conductivity for each material was standardized as per regulations or standard market specifications.

Following the standard (23), the horizontal joint is continuous for blocks $0.190 \mathrm{~m}$ thick, while for blocks $0.240 \mathrm{~m}$ and $0.290 \mathrm{~m}$ thick, mortar joint is discontinuous with $0.030 \mathrm{~m}$ air.

This study examines the following types of façade:

a) Single-leaf façade with a discontinuous joint and $0.030 \mathrm{~m}$ air space: This consisted of clay bricks with a normal thickness of $0.290 \mathrm{~m}$ (referred to here as "large format"), and bricks $0.240 \mathrm{~m}$ thick. These bricks were in general clad with a $0.015 \mathrm{~m}$ plaster rendering on the inside face, the thermal conductivity of which was $0.57 \mathrm{~W} / \mathrm{m} \cdot \mathrm{K}$, as per the relevant standard (23), and clad with mortar on the outside. In this case an ecological mortar consisting of lime, expanded perlite and hollow glass microspheres was used, with a thickness of around $0.025 \mathrm{~m}$ and a thermal conductivity of $0.068 \mathrm{~W} / \mathrm{m} \cdot \mathrm{K}$, according to the manufacturer (36). An example of the arrangement is shown in Fig. 3.

Single-leaf façades provide suitable levels of thermal insulation, offset and shock absorbance, together with excellent thermal inertia. This ensures that they perform well in both summer and winter.

b) Ventilated façades: this refers to walls made of clay bricks with an outer insulating layer of rigid polyurethane foam (PUR) with hydrofluorocarbon (HFC) applied to a thickness of $0.040 \mathrm{~m}$,

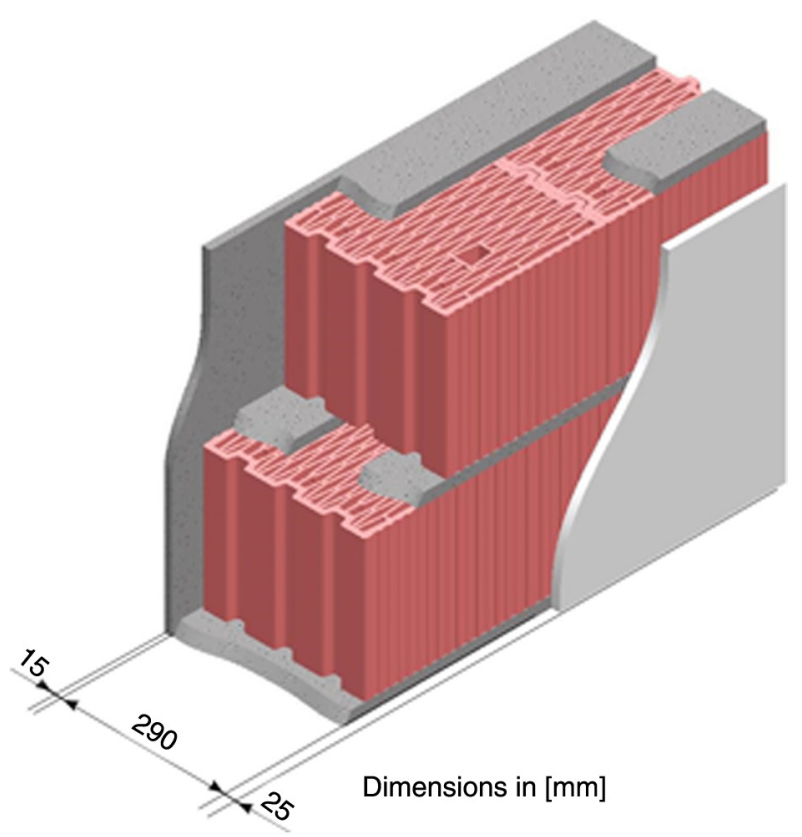

FIGURE 3. Single-leaf façade with blocks $0.290 \mathrm{~m}$ thick and discontinuous joint $0.030 \mathrm{~m}$ air, view from inside.

with a thermal conductivity of $0.028 \mathrm{~W} / \mathrm{m} \cdot \mathrm{K}$, as per the relevant standard (23), and interior cladding made of rendered plaster with a thickness of around $0.015 \mathrm{~m}$ and a thermal conductivity of $0.57 \mathrm{~W} / \mathrm{m} \cdot \mathrm{K}$, also as per the relevant standard (23), plus an outer sheet that was not fully sealed (37). The overall resistance of this outer sheet was calculated without taking into consideration the thermal resistance of the air space and all the other layers between that space and the outside atmosphere, but including an exterior surface resistance for still air conditions equal to the interior surface resistance of the same element, which for vertical façades is $0.13 \mathrm{~m}^{2} \cdot \mathrm{K} / \mathrm{W}$, in line with the relevant standard (28). An example of the arrangement is shown in Fig. 4.

Ventilated façades are a high-performance design for building envelopes whose main feature is to separate the role of waterproofing from the role of thermal insulation. They comply with all requirements in terms of thermal protection, energy saving and environmental protection.

c) Façade + ETICS (External Thermal Insulation Composite System): this refers to a façade with a thermal insulation system on the outside $(38,39)$. It consisted of clay bricks, inside cladding made of rendered plaster around $0.015 \mathrm{~m}$ thick, with a thermal conductivity of $0.57 \mathrm{~W} / \mathrm{m} \cdot \mathrm{K}$, in line with the relevant standard (23), and an ETICS outer sheet of insulating material attached to the wall mechanically, by adhesive or by a combination 


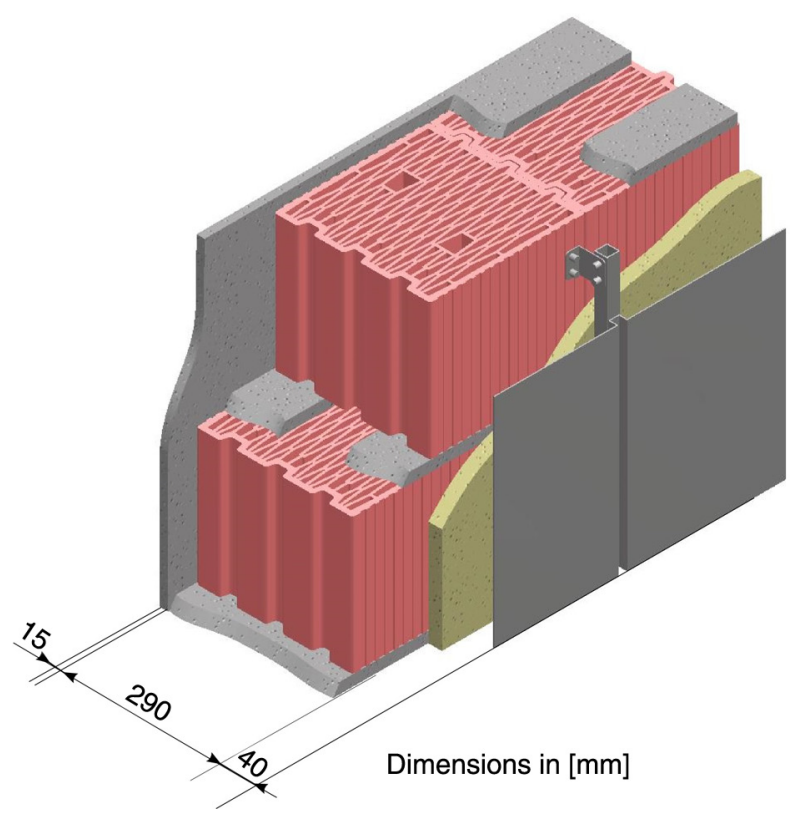

Figure 4. Ventilated façade with blocks $0.290 \mathrm{~m}$ thick and discontinuous joint $0.030 \mathrm{~m}$ air, view from outside.

of the two. The insulation was protected by cladding made up of one or more layers applied on site, one of which contained a reinforcing mesh. This cladding was applied directly onto the insulating panel, with no air space or discontinuous layer. It was around $0.040 \mathrm{~m}$ thick and its thermal conductivity was $0.037 \mathrm{~W} / \mathrm{m} \cdot \mathrm{K}(40)$. There was also exterior cladding with a thermal resistance of $0.020 \mathrm{~m}^{2} \cdot \mathrm{K} / \mathrm{W}$, compliant with the relevant standard (29). An example of the arrangement is shown in Fig. 5.

With the ETICS located on the outer face of the envelope, it contributes $90 \%$ of the envelope's mass to the building's thermal inertia. This outer insulation resolves any issues of thermal bridges, as the entire thickness of the insulating element is flush against the building envelope.

d) Façade + ITAICS (Internal Thermal Acoustic Insulation Composite System) $+\boldsymbol{L F B}$ (large format bricks): this consisted of clay with interior rendered plaster cladding around $0.015 \mathrm{~m}$ thick with a thermal conductivity of $0.57 \mathrm{~W} / \mathrm{m} \cdot \mathrm{K}$, compliant with the relevant Spanish standard (24), an inner sheet consisting of a large format partition with a thickness of around $0.070 \mathrm{~m}$ and a thermal conductivity of $0.290 \mathrm{~W} / \mathrm{m} \cdot \mathrm{K}$, in line with the relevant standard (24), then ITAICS consisting of glass wool around $0.050 \mathrm{~m}$ thick with a thermal conductivity of $0.036 \mathrm{~W} / \mathrm{m} \cdot \mathrm{K}$, in line with the relevant standard (41), a layer of pneumatically applied mortar around $0.005 \mathrm{~m}$ thick with a thermal conductivity of $0.650 \mathrm{~W} / \mathrm{m} \cdot \mathrm{K}(42)$, and an outer sheet consisting

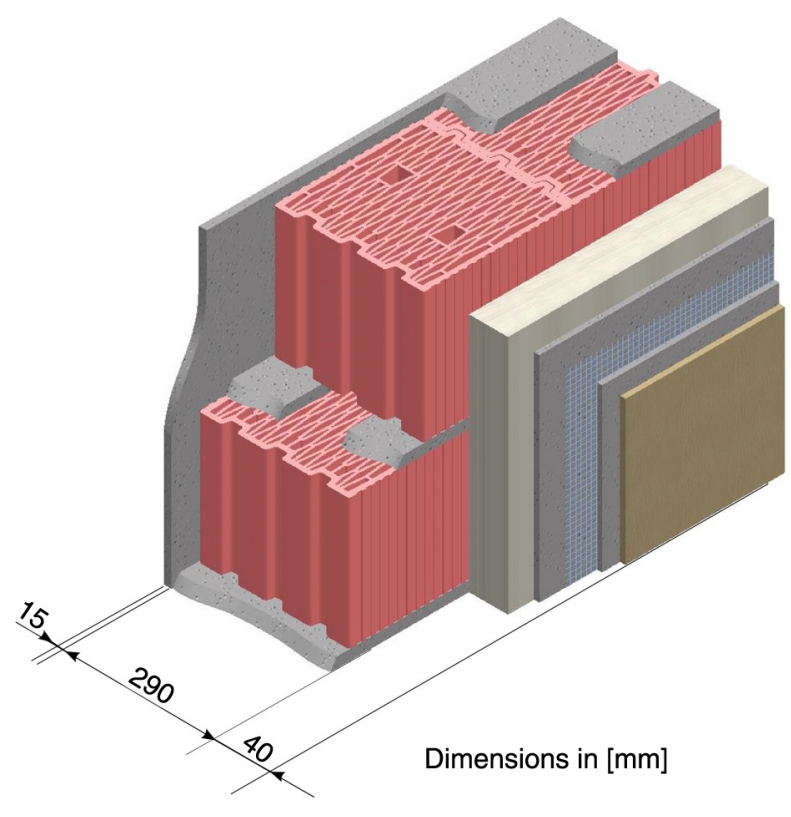

Figure 5. Façade with blocks $0.290 \mathrm{~m}$ thick and discontinuous joint $0.030 \mathrm{~m}$ air, and external thermal insulation composite system, view from outside.

of a Termoarcilla ${ }^{\mathrm{TM}}$ brick with an outside coating of mortar. In the case considered here standard mortar around $0.015 \mathrm{~m}$ thick was used, with a thermal conductivity of $1.300 \mathrm{~W} / \mathrm{m} \cdot \mathrm{K}$. An example of the arrangement is shown in Fig. $6(43,44)$.

\subsection{Thermal calculation method}

Thermal calculations were performed according to Spanish standards $(23,24)$, EN European Standards (25-30) and ISO International Standards $(31,32)$. The heat flows for the new bricks proposed were resolved using the finite element method (33), with the boundary conditions specified in the relevant standards.

The brick cross-section featured vertical perforations referred to as voids. The equivalent conductivity of the air in these voids can only be calculated if they are rectangular, so for non-rectangular voids an equivalent rectangular void was created in accordance with the standard (24). All the voids in the brick were considered as unventilated air spaces and the thermal conductivity of the air inside them was considered.

The thermal conductivity of the uncoated clay bricks thus obtained was then used to calculate the equivalent thermal transmittances of the four different types of façade proposed.

The target model for analysis by numerical methods was the part of the wall represented by the assembly of two bricks as shown in Fig. 7, where the assembly's three characteristic cross-sections can 


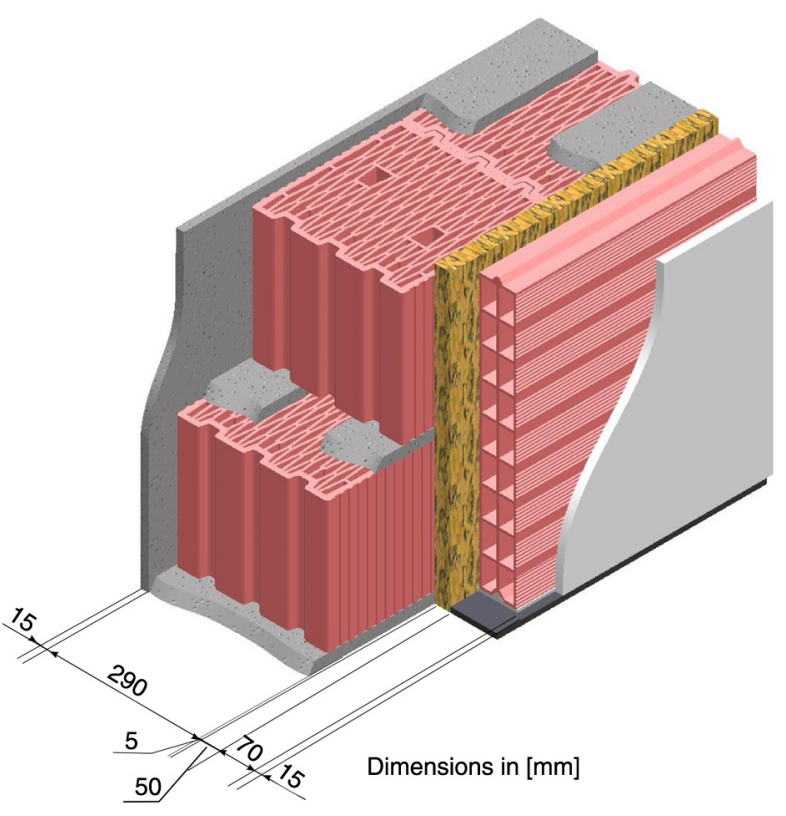

FIGURE 6. Facade with blocks $0.290 \mathrm{~m}$ thick and discontinuous joint $0.030 \mathrm{~m}$ air, and internal thermal acoustic insulation composite system, view from inside.

be seen, along with the height of each one: that of the brick with the voids full of air, referred to as the clay/air cross-section (height $h_{1}$ ), that of the brick with the voids full of binding mortar, referred to as the clay/mortar cross-section (height $h_{2}$ ), and that of the horizontal joint (the "tendel cross-section"), composed of binding mortar, with height $h_{3}$. These heights correspond to a type of standard assembly with binding mortar and penetration into the bricks.

Using the finite element method, the first two characteristic cross-sections of each wall (the "clay/ air cross-section" and the "clay/mortar crosssection") were obtained with the boundary conditions specified by the aforementioned standards, as shown in Fig. 8. This gave the heat flow through each characteristic cross-section, $Q_{i}$

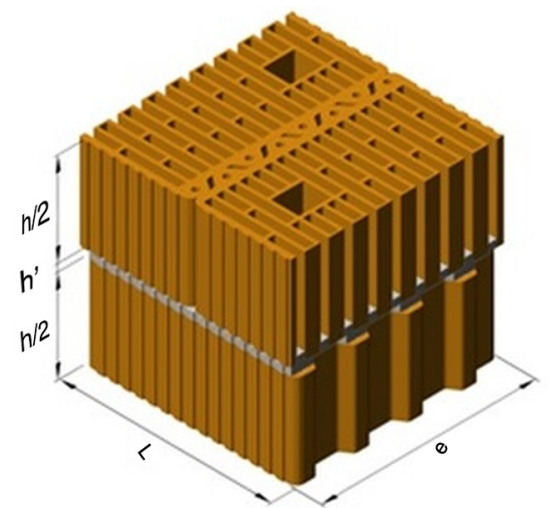

Once the heat flow, $Q_{i}$, had been calculated it was then possible to find the thermal resistance, $R_{i}$ by equation [1].

$$
R_{i}=\frac{L . \Delta T}{Q_{i}}-R_{i c}-R_{e c}
$$

$R_{1}$ is the resistance of the clay/air cross-section and $R_{i}$ is that of the clay/mortar cross-section.

For the horizontal joint, (the "tendel cross-section"), the data on the conductivity of the bonding mortar and the size of the air joint served immediately to calculate the resistance to the passage of heat:

- For a joint with standard mortar and a 0.030 $\mathrm{m}$ air gap resistance is given by equation [2].

$$
R_{3}=\frac{e-0,03}{\lambda_{m}}+\frac{0.03}{\lambda_{\text {air }}}
$$

- Whereas for a thin joint resistance is given by equation [3].

$$
R_{3}=\frac{e}{\lambda_{m}}
$$

Where $\lambda_{\mathrm{m}}$ is the conductivity of the bonding mortar, $\lambda_{\text {air }}$ is the conductivity of the air, and $e$ is the size of the air joint.

Based on the resistance value for each specific section, $R_{i}$, the overall resistance for the uncoated wall was determined, depending on the height of each specific section, $h_{i}$, using equation [4].

$$
R_{U W}=\frac{h_{1}+h_{2}+h_{3}}{\frac{h_{1}}{R_{1}}+\frac{h_{2}}{R_{2}}+\frac{h_{3}}{R_{3}}}
$$

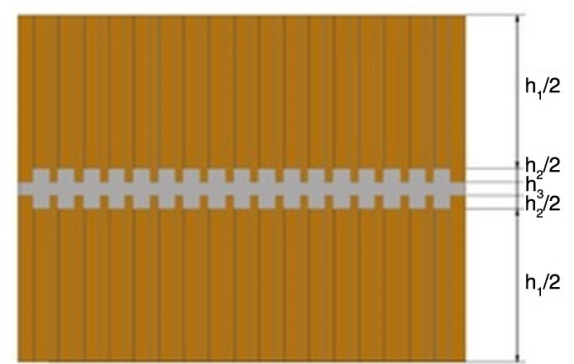

FIGURE 7. Part of the wall representing the assembly of two blocks and the heights of each characteristic cross-section. 


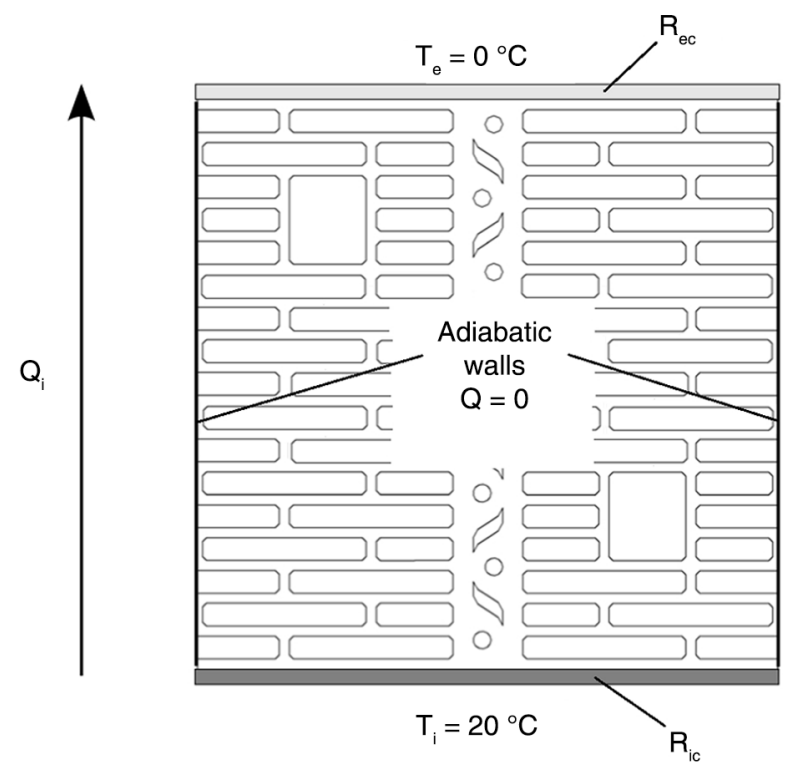

FiguRE 8. Boundary conditions for obtaining the heat flow, $Q_{1}$.

The data on the conductivity of the component material enabled the resistance to the passage of heat of all the other layers that made up the façade to be calculated immediately via equation [5].

$$
R_{n}=\frac{e}{\lambda_{n}}
$$

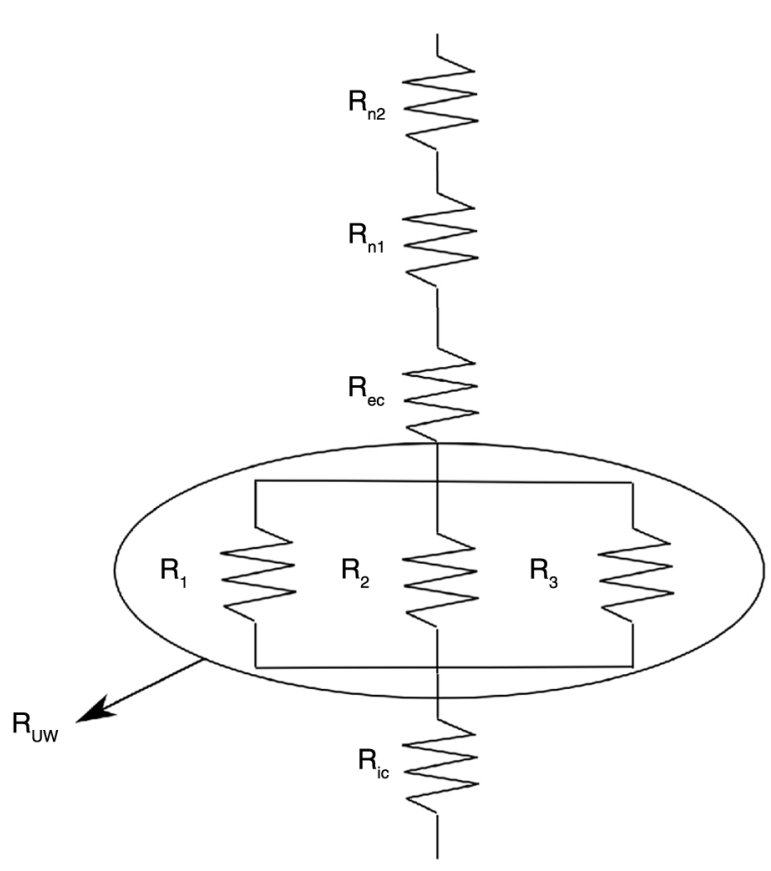

FIGURE 9. Thermal network.
Finally, the equivalent thermal transmittance of the envelope cladding was obtained for each of the four types of façade using equation [6].

$$
U_{i}=\frac{1}{R_{T}}=\frac{1}{R_{i c}+R_{U W}+R_{n 1}+\ldots+R_{n i}+R_{e c}}
$$

Where $R_{i c}$ and $R_{e c}$ are the thermal resistance of the internal and external cladding, $R_{U W}$ is the thermal resistance of the uncoated wall and $R_{n}$ is the thermal resistance of each layer of insulating materials, air spaces, etc. in the wall.

For the sake of clarity, a schematic of the thermal network is shown in Fig. 9.

\section{RESULTS AND DISCUSSION}

\subsection{Thermal results for commercial Termoarcilla ${ }^{\mathrm{TM}}$ bricks with herringbone voids, used as a reference}

To compare the results for the new bricks proposed, we sought to characterize the four types of wall assemblies with commercial bricks with herringbone voids, referred to as type 29, 24 and 19 Termoarcilla ${ }^{\mathrm{TM}}$ bricks.

As mentioned above, several manufacturers that market these bricks certify a thermal transmittance of around $0.500 \mathrm{~W} / \mathrm{m} \cdot \mathrm{K}$ (44) for their uncoated bricks based on the thermal conductivity of the clays used in them. The thermal resistances of the uncoated bricks are shown in Table 1.

It should be noted that the walls with $0.290 \mathrm{~m}$ and $0.240 \mathrm{~m}$ bricks considered were made with a discontinuous joint with a $0.030 \mathrm{~m}$ air space, in compliance with the relevant standards (23-32). However the standards do not permit discontinuous joints with the $0.190 \mathrm{~m}$ brick, so in that case a continuous mortar joint was used. This means that there were major differences in the thermal conductivity of the bricks.

The data for the thermal resistance of each brick enabled the equivalent thermal transmittance for each type of façade under study to be obtained. Table 2 shows the values for each layer in the building arrangement used for the façade for each assembly using Termoarcilla ${ }^{\mathrm{TM}} 29$ bricks, thereby providing the equivalent thermal transmittance.

Once the reference assembly had been characterized for each type of façade, the next step was to compare the thermal results for the façades made with the different thicknesses of commercial bricks proposed for the study.

Table 3 shows the equivalent thermal transmittances of the different types of façade and the thicknesses of the walls in question, indicating by how much each type of façade reduced the useful surface area of the housing unit.

As can be seen, a single-leaf façade made of Termoarcilla $^{\mathrm{TM}} 29$ brick was found to comply with 
TABle 1. Properties of Termoarcilla ${ }^{\mathrm{TM}}$ bricks

\begin{tabular}{lccc}
\hline Name & $\begin{array}{c}\text { THICKNESS } \\
(\mathbf{m})\end{array}$ & $\begin{array}{c}\text { THERMAL } \\
\text { CONDUCTIVITY }(\mathbf{W} / \mathbf{m} \cdot \mathbf{k})\end{array}$ & $\begin{array}{c}\text { THERMAL RESISTANCE } \\
\text { UNCOATED }\left(\mathbf{m}^{2} \cdot \mathbf{K} / \mathbf{W}\right)\end{array}$ \\
\hline Termoarcilla $^{\mathrm{TM}} 29$ & 0.290 & 0.240 & 1.208 \\
Termoarcilla $^{\mathrm{TM}} 24$ & 0.240 & 0.240 & 1.000 \\
Termoarcilla $^{\mathrm{TM}} 19$ & 0.190 & 0.280 & 0.679 \\
\hline
\end{tabular}

TABLE 2. Values of each layer in the different types of façades made from a main brick of Termoarcilla ${ }^{\mathrm{TM}} 29$, and equivalent thermal transmittance obtained

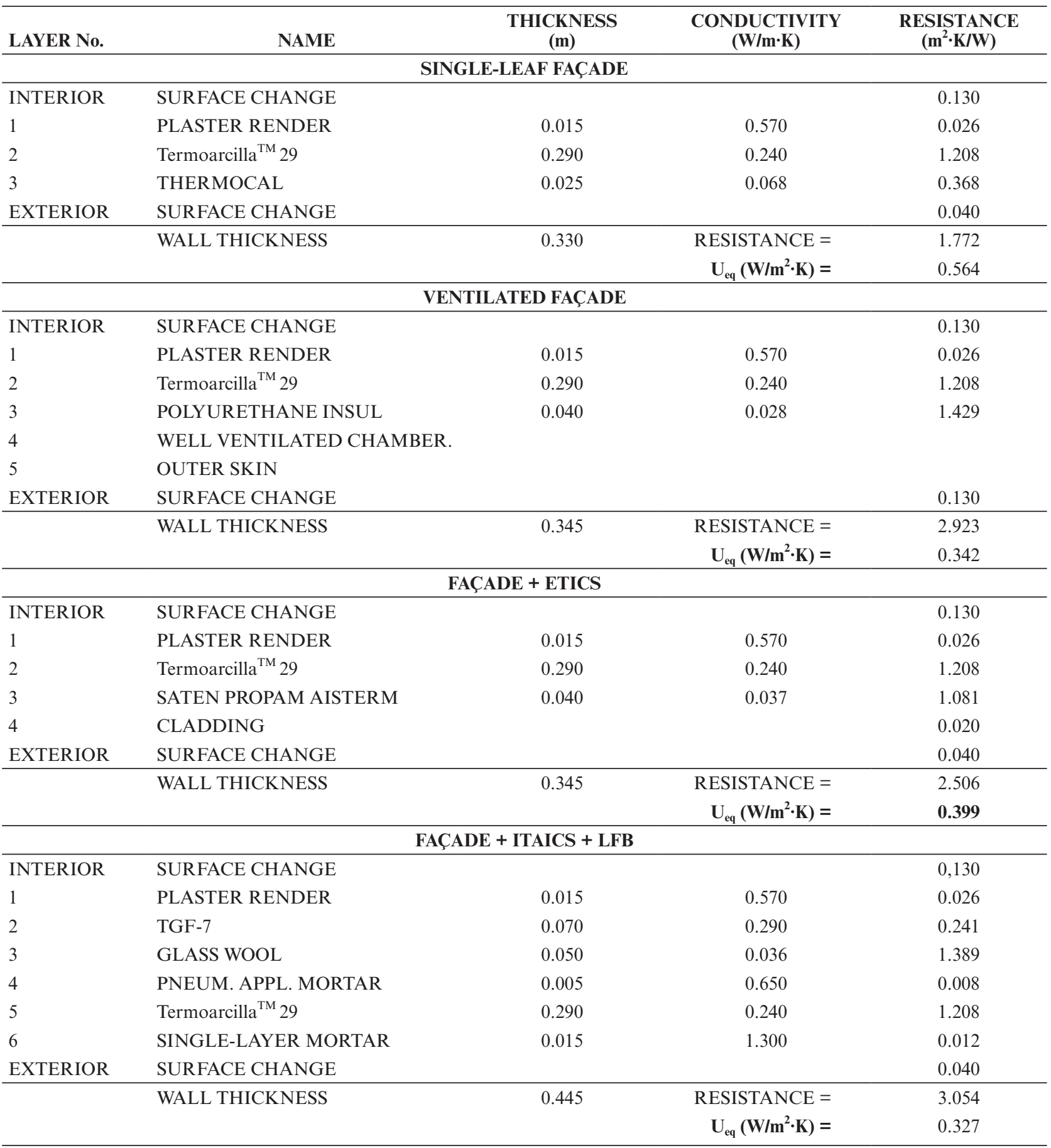


TABLE 3. Equivalent thermal transmittance of the envelope for each type of façade with commercial bricks and thicknesses affecting the useful surface area of the housing unit

\begin{tabular}{|c|c|c|c|c|c|c|}
\hline & \multicolumn{3}{|c|}{ THICKNESSES (m) } & \multicolumn{3}{|c|}{$\operatorname{Ueq}\left(\mathrm{W} / \mathrm{m}^{2} \cdot \mathrm{K}\right)$} \\
\hline & TA-29 & TA-24 & TA-19 & TA-29 & TA-24 & TA-19 \\
\hline SINGLE-LEAF FAÇADE & 0.330 & 0.280 & 0.230 & 0.564 & 0.639 & 0.805 \\
\hline VENTILATED FAÇADE & 0.345 & 0.295 & 0.245 & 0.342 & 0.368 & 0.418 \\
\hline FAÇADE + ETICS & 0.345 & 0.295 & 0.245 & 0.399 & 0.435 & 0.506 \\
\hline FAÇADE + ITAICS + LFB & 0.445 & 0.395 & 0.345 & 0.327 & 0.370 & 0.396 \\
\hline
\end{tabular}

the strict standard that specifies $0.570 \mathrm{~W} / \mathrm{m}^{2} \cdot \mathrm{K}$ as the most restrictive value in the most climatically adverse regions $(23,24)$, whereas the other two bricks proved unacceptable for such regions. By contrast, all the other types of façade showed very good thermal values, regardless of the brick.

The best solution found here was clearly the ventilated façade with a type 24 or 29 brick, with an equivalent thermal transmittance of around $0.350 \mathrm{~W} / \mathrm{m}^{2} \cdot \mathrm{K}$ and a reduction of less than $0.350 \mathrm{~m}$ in the useful area of the housing unit. This thickness may however be considered excessive for housing units. Depending on the thermal requirements in each building, the façade + ITAICS+ LFB with a Termoarcilla ${ }^{\mathrm{TM}} 19$ brick could be considered as acceptable.

\subsection{Thermal results for the proposed Termoarcilla ${ }^{\mathrm{TM}}$ bricks with rhomboidal internal voids}

This study involved a proposed brick with the same dimensions as the commercial Termoarcilla ${ }^{\mathrm{TM}}$ bricks with rhomboidal voids to optimize its internal geometry (10). The design consisted of rhomboidal voids that extended to the tongue and groove area, thus giving the brick a thermal break at the vertical joint, as shown above (14-17).

Fig. 10 displays the cross-sections of the three bricks under study, showing that the $0.290 \mathrm{~m}$ brick has three tongues and three grooves, while the $0.240 \mathrm{~m}$ and $0.190 \mathrm{~m}$ bricks have only two grooves and two tongues. This arrangement is required in order to extrude the pieces by resting the brick on the grooved face. If they were extruded on the faces without tongue and grooving there would be a bellows effect.

An analysis of the specific cross-sections of each type of wall showed that the $0.290 \mathrm{~m}$ and $0.240 \mathrm{~m}$

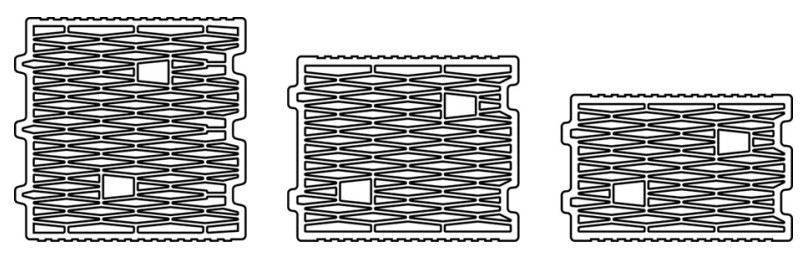

FIGURE 10. Cross-section of the proposed bricks under study. thick bricks had a discontinuous horizontal joint with an air space $0.030 \mathrm{~m}$ wide, while the $0.190 \mathrm{~m}$ brick had a continuous joint. Finite element software (33) was used, with the boundary conditions specified in the standards, to obtain the heat flows passing through the clay/air cross-section, the clay/mortar cross-section, and the horizontal joint. Considering the height of each specific section, these heat flows enabled the resistance of the uncoated wall for each brick under study to be obtained.

Fig. 11 shows the heat flow diagram for the specific clay/air cross-sections (a clay cross-section with air-filled voids) for the proposed brick with a thickness of $0.240 \mathrm{~m}$.

Table 4 shows the figures for the equivalent thermal transmittance of the different types of façade and the thicknesses of the walls in question, to indicate by how much each type of façade reduces the useful surface area of the housing unit.

The results provided by the bricks proposed revealed that for single-leaf façades, $0.290 \mathrm{~m}$ and $0.240 \mathrm{~m}$ thick bricks met the standards applicable in the most restrictive Spanish regions, where an equivalent thermal transmittance of less than $0.570 \mathrm{~W} / \mathrm{m}^{2} \cdot \mathrm{K}$ is required.

Equivalent thermal transmittances below 0.300 $\mathrm{W} / \mathrm{m}^{2} \cdot \mathrm{K}$ were also observed: such figures were not obtained with any of the wall types using the commercial herringbone bricks.

\subsection{Comparative analysis}

A joint analysis of the figures in Tables 3 and 4 served to compare the percentage improvements between the commercial herringbone bricks and the rhomboidal bricks proposed here. The results are shown in Table 5.

The $0.290 \mathrm{~m}$ and $0.240 \mathrm{~m}$ bricks showed improvements of more than $13 \%$ for single-leaf façades, which we consider to be a very important result. For $0.190 \mathrm{~m}$ bricks the improvement in such walls was not so great.

In general the $0.190 \mathrm{~m}$ brick showed no significant differences for almost any type of façade, which means that it is not worth changing the internal geometry of bricks of that specific thickness. 


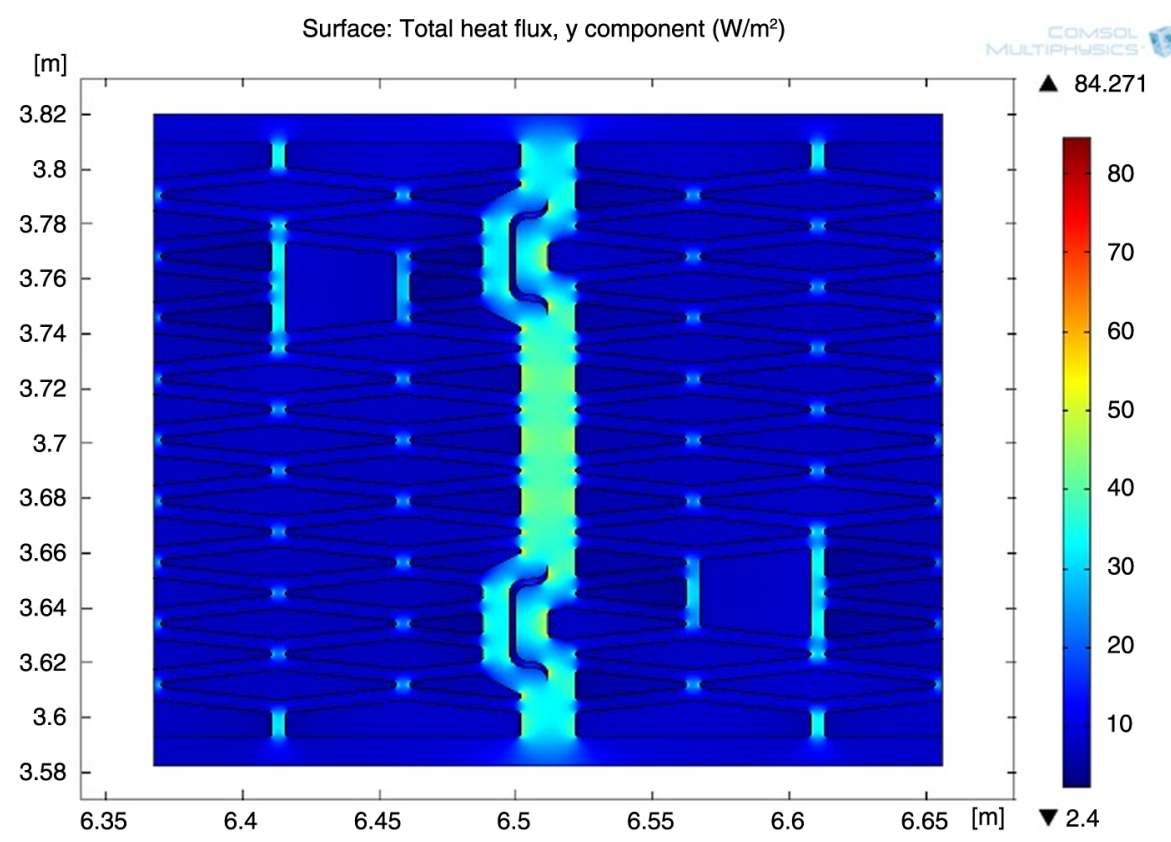

FIGURE 11. Heat flow of the specific clay/air cross-section for the proposed brick with a thickness of $0.240 \mathrm{~m}$.

TABLE 4. Equivalent thermal transmittance of the envelope for each type of façade with the proposed Termoarcilla ${ }^{\mathrm{TM}}$ bricks $^{\mathrm{s}}$ with rhomboidal internal voids and thicknesses affecting the useful surface area of the housing unit

\begin{tabular}{|c|c|c|c|c|c|c|}
\hline & \multicolumn{3}{|c|}{ THICKNESSES (m) } & \multicolumn{3}{|c|}{$\mathbf{U}_{\mathrm{eq}}\left(\mathbf{W} / \mathbf{m}^{2} \cdot \mathbf{K}\right)$} \\
\hline & TA-29 & TA-24 & TA-19 & TA-29 & TA-24 & TA-19 \\
\hline SINGLE-LEAF FAÇADE & 0.330 & 0.280 & 0.230 & 0.486 & 0.556 & 0.767 \\
\hline VENTILATED FAÇADE & 0.345 & 0.295 & 0.245 & 0.312 & 0.339 & 0.407 \\
\hline FAÇADE + ETICS & 0.345 & 0.295 & 0.245 & 0.358 & 0.395 & 0.491 \\
\hline FAÇADE + ITAICS + LFB & 0.445 & 0.395 & 0.345 & 0.299 & 0.325 & 0.387 \\
\hline
\end{tabular}

TABLE 5. Comparison in \% of improvement in types of façade between the bricks proposed and commercial bricks

\begin{tabular}{|c|c|c|c|c|c|c|c|c|c|}
\hline & \multicolumn{6}{|c|}{$\mathrm{U}_{\mathrm{eq}}\left(\mathrm{W} / \mathrm{m}^{2} \cdot \mathrm{K}\right)$} & \multirow{2}{*}{\multicolumn{3}{|c|}{$\begin{array}{c}\text { \% IMPROVEMENT } \\
\text { RHOMB/HERRINGBONE }\end{array}$}} \\
\hline & \multicolumn{3}{|c|}{ HERRINGBONE } & \multicolumn{3}{|c|}{ RHOMBOIDAL } & & & \\
\hline & TA-29 & TA-24 & TA-19 & TA-29 & TA-24 & TA-19 & TA-29 & TA-24 & TA-19 \\
\hline SINGLE-LEAF FAÇADE & 0.564 & 0.639 & 0.805 & 0.486 & 0.556 & 0.767 & $-14 \%$ & $-13 \%$ & $-5 \%$ \\
\hline VENTILATED FAÇADE & 0.342 & 0.368 & 0.418 & 0.312 & 0.339 & 0.407 & $-9 \%$ & $-8 \%$ & $-2 \%$ \\
\hline FAÇADE + ETICS & 0.399 & 0.435 & 0.506 & 0.358 & 0.395 & 0.491 & $-10 \%$ & $-9 \%$ & $-3 \%$ \\
\hline FAÇADE + ITAICS + LFB & 0.327 & 0.370 & 0.396 & 0.299 & 0.325 & 0.387 & $-9 \%$ & $-12 \%$ & $-2 \%$ \\
\hline
\end{tabular}

By contrast, the thermal improvements for the $0.290 \mathrm{~m}$ and $0.240 \mathrm{~m}$ bricks were significant for all the types of façade proposed here, ranging between $8 \%$ and $14 \%$. These improvements can be considered important in terms of the thermal insulation of façades.

As shown in Tables 4 and 5, assuming an acceptable façade thickness of $0.300 \mathrm{~m}$, single-leaf, ventilated and ETICS façades would be acceptable for similar façade thicknesses only with 0.240 and $0.190 \mathrm{~m}$ bricks. As mentioned above, little difference was found between commercial herringbone bricks and rhomboidal ones in the $0.190 \mathrm{~m}$ case.

The $0.240 \mathrm{~m}$ rhomboidal brick proposed here showed an improvement of between $8 \%$ and $13 \%$, and can therefore be considered as recommendable.

The best value recorded for equivalent thermal transmittance was $0.299 \mathrm{~W} / \mathrm{m}^{2} \cdot \mathrm{K}$, for the rhomboidal brick on the façade + ITAICS + LFB, where there was a $9 \%$ improvement on the performance of the commercial herringbone brick for the same type of wall. However this type of façade is $0.445 \mathrm{~m}$ 
thick, which may be considered somewhat high as it reduces the useful surface area of the housing unit. Its use would therefore depend on the thermal requirements of each building.

\section{CONCLUSIONS}

The use of clay bricks in façades provides building envelopes with good thermal performance levels. This paper reports a study comparing the equivalent thermal transmittances of façades for two kinds of brick: one that is commercially available and another proposed by the authors, using three different brick thicknesses and four types of façade: single-leaf façades, ventilated façades, façades with an exterior thermal insulation system and façades with internal thermo-acoustic insulation and a large format brick on the inside.

Commercial Termoarcilla ${ }^{\mathrm{TM}}$ bricks with herringbone internal voids were used as a baseline reference, but the study focused on bricks with rhomboidal internal voids. All the bricks used had the same outside face measurements. Thicknesses of $0.290 \mathrm{~m}$, $0.240 \mathrm{~m}$ and $0.190 \mathrm{~m}$ were studied.

It can be concluded that the $0.190 \mathrm{~m}$ thick rhomboidal brick proposed offers little improvement on the $0.190 \mathrm{~m}$ brick already commercially available: the improvement is less than $5 \%$ in the best of cases. This type of brick has a continuous horizontal joint, while the other two types have discontinuous joints with a $0.030 \mathrm{~m}$ air space. By contrast, the thermal performances of the $0.290 \mathrm{~m}$ and $0.240 \mathrm{~m}$ rhomboidal bricks proposed were between $8 \%$ and $14 \%$ better than those of the commercially available bricks for all the types of wall studied.

For single-leaf façades the thermal performances recorded for the $0.290 \mathrm{~m}$ and $0.240 \mathrm{~m}$ bricks proposed were better by a highly significant $13 \%-14 \%$, with a thermal transmittance of $0.486 \mathrm{~W} / \mathrm{m}^{2} \cdot \mathrm{K}$ for the $0.290 \mathrm{~m}$ brick.

If façades must not exceed $0.350 \mathrm{~m}$ in thickness, only $0.190 \mathrm{~m}$ thick bricks can feasibly be used on multilayer façades with thermo-acoustic insulation and a large format brick on the inside. In this case, the equivalent thermal transmittance would be close to $0.400 \mathrm{~W} / \mathrm{m}^{2} \cdot \mathrm{K}$. For either of the other two bricks the façade thickness would exceed $0.400 \mathrm{~m}$.

Equivalent thermal transmittances of 0.300 $\mathrm{W} / \mathrm{m}^{2} \cdot \mathrm{K}$ were recorded for the $0.290 \mathrm{~m}$ thick rhomboidal brick on façades with thermo-acoustic insulation and a large format brick on the inside, but the final thickness of the wall was $0.445 \mathrm{~m}$.

For ventilated façades the $0.290 \mathrm{~m}$ and $0.240 \mathrm{~m}$ thick rhomboidal bricks proposed gave 8\%-9\% improvements, with values of $0.312 \mathrm{~W} / \mathrm{m}^{2} \cdot \mathrm{K}$ and $0.339 \mathrm{~W} / \mathrm{m}^{2} \cdot \mathrm{K}$, respectively. In view of the small difference in thermal terms, the best option would therefore be to use $0.240 \mathrm{~m}$ bricks, as the overall thickness of the façade would not then exceed $0.300 \mathrm{~m}$.

\section{REFERENCES}

1. Theodosiou, T.G.; Papadopoulos, A.M. (2007) The impact of thermal bridges on the energy demand of buildings with double brick wall constructions. Energ. Buildings 40 [11], 2083-2089. http://dx.doi.org/10.1016/j.enbuild.2008.06.006.

2. Eurostat 2013. Energy, transport and environment indicators. ISSN 1725-4566. (online data code: nrg_100a). http://ec.europa.eu/eurostat/documents/3930297/5968878/ KS-DK-13-001-EN.PDF.

3. Raimondo, M.; Dondi, M.; Mazzanti, F.; Stefanizzi, P.; Bondi, P. (2005) Equilibrium moisture content of clay bricks: The influence of the porous structure, Build. Environ. 42 [2], 926-932. http://dx.doi.org/10.1016/j.buildenv.2005.10.017.

4. Antar Mohamed, A. (2010) Thermal radiation role in conjugate heat transfer across a multiple-cavity building brick, Energy 35 [8], 3508-3516. http://dx.doi.org/10.1016/j.energy. 2010.04 .055

5. García, X. (2003) Idoneidad de los cerramientos monocapa para viviendas Bioclimáticas en emplazamientos de elevada severidad climática, Universidad Pontíficia Comillas de Madrid. Instituto de Investigación Tecnológica. http:// www.iit.upcomillas.es/publicaciones/mostrar_publicacion_ working_paper.php.en?id=66.

6. Morales, M.P.; Juárez, M.C.; López-Ochoa, L.M.; Doménech, J. (2010) Study of the geometry of a voided clay brick using rectangular perforations to optimize its thermal properties, Appl. Therm. Eng. 31 [11-12], 2063-2065. http:// dx.doi.org/10.1016/j.applthermaleng.2011.02.033.

7. Sastre, V. (2008) Bloques cerámicos de alto aislamiento térmico, Termoarcilla ECO, Con arquitectura. http://www. conarquitectura.com/articulos/24-10-2012-12-50-07-26. pdf (Accessed February 2016).

8. Consorcio Termoarcilla \& LabeinTecnalia (2005) Investigación de las condiciones del Bloque Termoarcilla para el cumplimiento de las exigencias del nuevo CTE. Propiedades térmicas. www.termoarcilla.com.

9. Li, L.P.; Wu, Z.G.; He, Y.L.; Lauriat, G.; Tao, W.Q. (2008) Optimization of the configuration of $290 \times 140 \times 90$ hollow clay bricks with 3-D numerical simulation by finite volume method, Energ. Buildings 40 [10], 1790-1798. http://dx.doi. org/10.1016/j.enbuild.2008.03.010.

10. Morales, M.P.; Juárez, M.C.; Muñoz, P.; Gómez, J.A. (2011) Study of the geometry of a voided clay brick using non-rectangular perforations to optimise its thermal properties, Energ. Buildings 43 [9], 2494-2498. http://dx.doi.org/ 10.1016/j.enbuild.2011.06.006.

11. Lourenco, P.B.; Vasconcelos, G.; Medeiros, P.; Gouveia, J. (2010) Vertically perforated clay brick masonry for loadbearing and non-loadbearing masonry walls. Constr. Build. Mater. 24, 2317-2330. http://dx.doi.org/10.1016/j. conbuildmat.2010.04.010.

12. Del Coz Díaz, J.J.; Neto, P.J.G.; Sierra, J.L.S.; Biempica, C.B. (2008) Nonlinear thermal optimization of external light concrete multi-holed brick walls by finite element method. Int. J. Heat Mass Trans. 51, 1530-1541. http:// dx.doi.org/10.1016/j.ijheatmasstransfer.2007.07.029.

13. Li, L.P.; Wu, Z.G.; He, Y.L.; Lauriat, G.; Tao, W.Q. (2008) Numerical thermal optimization of the configuration of multi-holed clay bricks used for constructing building walls by the finite volume method. Int. J. Heat Mass Trans. 51, 3669-3682. http://dx.doi.org/10.1016/j.ijheatmasstransfer.2007.06.008

14. Morales, M.P.; Juárez, M.C.; López-Ochoa, L.M.; Muñoz, P. (2012) Influence of tongue and groove system on the thermal properties of large-format voided clay bricks for single-leaf walls, Constr. Build. Mater. 30, 169-173. http:// dx.doi.org/10.1016/j.conbuildmat.2011.12.006.

15. Ghazi Wakili, K.; Tanner, Ch. (2003) U-value of a dried wall made of perforated porous clay bricks: Hot box measurement versus numerical analysis, Energ. Buildings 35 [7], 675-680. http://dx.doi.org/10.1016/ S0378-7788(02)00209-8.

16. Juárez, M.C.; Morales, M.P.; Muñoz, P.; Gómez, J.A. (2012) Influence of Horizontal Joint on the Thermal Properties of Single-leaf Walls with Lightweight Clay Bricks, Energ. 
Buildings 49, 362-366. http://dx.doi.org/10.1016/j.enbuild. 2012.02.033

17. Morales, M.P.; Juárez, M.C.; Muñoz, P.; Mendívil, M.A.; Ruiz, J.A. (2014) Possibilities for improving the equivalent thermal transmittance of single-leaf walls for buildings, Energ. Buildings 69, 473-480. http://dx.doi.org/10.1016/j. enbuild.2013.11.038

18. Luciana, C.S. Herek; Carla Eponina, Hori; Miria Hespanhol, Miranda Reis; Diaz Mora, Nora; Granhem Tavares, Célia Regina; Bergamasco, Rosângela (2012) Characterization of ceramic bricks incorporated with textile laundry sludge, Ceram. Int. 38 [2], 951-959. http://dx.doi.org/10.1016/j. ceramint.2011.08.015.

19. Alonso-Santurde, R.; Coz, A.; Viguri, J.R.: Andrés, A. (2012) Recycling of foundry by-products in the ceramic industry: Green and core sand in clay bricks. Constr. Build. Mater. 27, 97-106. http://dx.doi.org/10.1016/j.conbuildmat.2011.08.022.

20. Bilgin, N.; Yeprem, H.A.; Arslan, S.; Bilgin, A.; Günay, E.; Marsoglu, M. (2012) Use of waste marble powder in brick industry. Constr. Build. Mater. 29, 449-457. http:// dx.doi.org/10.1016/j.conbuildmat.2011.10.011.

21. Muñoz, P.; Juárez, M.C.; Morales, M.P.; Mendívil, M.A. (2013) Improving the thermal transmittance of singlebrick wall built of clay bricks lightened with paper pulp. Energ. Buildings 59, 171-180. http://dx.doi.org/10.1016/j. enbuild.2012.12.022.

22. Raut, S.P.; Ralegaonkar, R.V.; Mandavgane, S.A. (2011) Development of sustainable construction material using industrial and agricultural solid waste: A review of wastecreate bricks. Constr. Build. Mater. 25, 4037-4042. http:// dx.doi.org/10.1016/j.conbuildmat.2011.04.038.

23. Spanish Standard. "Código Técnico de la Edificación. Documento Básico. Ahorro de Energía”. CTE-DB-HE (2006). http://www.codigotecnico.org (Accessed February 2016).

24. Spanish Standard. "Reglamento particular de la marca AENOR para piezas de arcilla cocida para fábricas a revestir". AENOR RP 34-14. (2009). http://www.aenor.es/ documentos/certificacion/reglamentos/w_RP_34-14_200906-01.pdf (Accessed February 2016).

25. European Standard, EN 12939:2000, Thermal performance of building materials and products - determination of thermal resistance by means of guarded hot plate and heat flow meter methods - thick products of high and medium thermal resistance. European Committee for Standardization.

26. European Standard, EN 12664:2001, thermal performance of building materials and products - determination of thermal resistance by means of guarded hot plate and heat flow meter methods - dry and moist products of medium and low thermal resistance. European Committee for Standardization.

27. European Standard, EN 1745:2002, "Masonry and masonry products. Methods for determining design thermal values".

28. European and International Standard, EN ISO 6946:1996, "Building components and building elements. Thermal resistance and thermal transmittance. Calculation method.".

29. European and International Standard, EN ISO 10 211-1:1995, "Thermal bridges in building construction. Heat flows and surface temperatures. Part 1: General calculation methods".
30. European and International Standard, EN ISO 10 2112:2002, "Thermal bridges in building construction. Heat flows and surface temperatures. Part 2: Thermal linear bridges".

31. International Standard, ISO 10456:2007 "Building materials and products. Procedures for determining declared and design thermal values" http://www.iso.org/iso/catalogue detail.htm\%3Fcsnumber=40966 (Accessed February 2016).

32. International Standard, ISO 8990:1994, 2006. p. 50748. Thermal insulation - determination of steady-state thermal transmission properties - calibrated and guarded hotbox.

33. COMSOL 4.2a (2005) Multiphysics Modeling and Engineering Simulation Software. [CD ROM] COMSOL AB; http://www.comsol.com (Accessed February 2016)

34. Interempresas. CerámicaUtzubar. https://www.interempresas.net/Construccion/FeriaVirtual/Producto-TermoarcillasUtzubar-Bloque-88514.html (Accessed February 2016).

35. Vivancos, J.L.; Soto, J.; Pérez, I.; Ros-Lis, J.V.; MartínezMáñez, R. (2009) A new model based on experimental results for the thermal characterization of bricks, Build. Environ. 44 [5], 1047-1052. http://dx.doi.org/10.1016/j. buildenv.2008.07.016.

36. Thermoacustical para la edificación. WÜRTH. http:// www.wurth.es/media/pdf_folletos/thermoacustical.pdf (Accessed February 2016).

37. Cuantificación de la eficiencia de la fachada cerámica ventilada mediante técnicas de la mecánica de fluidos computacional (2011). Bol. Soc. Esp. Ceram. Vidr. 50 [2], 99-108. http://dx.doi.org/10.3989/cyv.142011.

38. Mandilaras, I.; Atsonios, I.; Zannis, G.; Founti, M. (2014) Thermal performance of a building envelope incorporating ETICS with vacuum insulation panels and EPSI, Energ. Buildings 85, 654-665 2014. http://dx.doi.org/10.1016/j. enbuild.2014.06.053.

39. Barreira, E; de Freitas, V.P. (2013) Experimental study of the hygrothermal behaviour of External Thermal Insulation Composite Systems (ETICS), Build. Environ. 63, 31-39. http://dx.doi.org/10.1016/j.buildenv.2013.02.001.

40. Ventajas técnicas de los sistemas de aislamiento de fachadas por el exterior. Técnica Constructiva (2011) Colegio de Aparejadores, Arquitectos Técnicos e Ingenieros de la Edificación de Valencia. http://www.caatvalencia.es/articulos/ 2012/VIR02125.pdf (Accessed February 2016)

41. European and International Standard, UNE-EN 13162:2009, "Thermal insulation products for buildings-Factory made mineral wool (MW) products-Specification."

42. European and International Standard. UNE-EN 998-2:2012, "Specification for mortar for masonry-Part 2: Masonry mortar".

43. Cerámica Marlo. Soluciones constructivas. http://www. ceramicamarlo.com/es/soluciones-constructivas-familia. asp?id_tipo $=3$ (Accessed February 2016).

44. Isober. Saint Gobain http://www.isover.es/Aislamiento-en-laEdificacion/Aplicaciones/Aplicaciones-EdificacionResidencial/PARTICIONES - INTERIORES -VERTICALES-Y-MEDIANERIAS/Elementos-dedos-hojas.-Tipo-2./Elementos-dos-hojas.-Tipo-2-P3.2/ Descripcion (Accessed February 2016). 